\title{
Functional Literacy in People's Lives
}

Milada Rabušicová, Pavla Oplatková

\begin{abstract}
The paper presents the results of a qualitative study into the lives of people with inadequate functional literacy skills. The data were collected through a biographical interview with a respondent whose characteristics correspond to those of a hypothetical person likely to exhibit signs of low functional literacy. The characteristics, such as gender, age, parental education achievements and job history, of this hypothetical person have been derived from the results of research into adult functional literacy undertaken in the Czech Republic in 1998 - International Adult Literacy Survey (IALS). The analysis of the qualitative data focuses on three domains of the respondent's life, namely her family life, her school years, and her life style. The paper identifies the coping strategies used by the respondent in her everyday life.
\end{abstract}

Key words: Functional literacy, biographical interview technique, family life, life style, educational and occupational history, life strategy.

\section{Introduction}

The paper is based on two main sources: Literacy: A New Perspective on a Traditional Topic [Rabušicová 2002] and a master's thesis ${ }^{1}$ called "Functional Adult Literacy in Human Life" [Oplatková 2010]. Rabušicová's book is the first to present the phenomenon of functional literacy in the Czech Republic in some detail, relying mainly on the results of a survey undertaken in this country in 1998 as a part of the International Adult Literacy Survey (IALS). It involved testing the adult population aged between 16 and 65 for prose (reading), document and quantitative literacy and included a questionnaire survey with context variables to characterize the respondents. The results were interpreted in terms of causes and consequences and by finding links between functional literacy and the person's job and their everyday life. The

1 The thesis was defended at the Department of Educational Sciences, Faculty of Arts, Masaryk University, Brno in January 2010. 
book concludes with a description of a hypothetical person likely to exhibit symptoms of low literacy - based on the quantitative data - and mentions that no qualitative study offering details of what life is like for these people has been undertaken in the Czech Republic. This challenge was taken up by the second author of this paper in her master's thesis. The results of her qualitative analysis are used here.

\section{Theoretical starting points}

Research into functional literacy ${ }^{2}$ has profited considerably from quantitative research methodologies; quantitative research provided essential information on, for instance, functional literacy measurement methodologies and the distribution of functional literacy levels across the national and international populations. It has identified statistical correlations between functional literacy levels and education, job, age in the population and underlined the characteristics of individuals suffering from low literacy. It transpires that a person with a low literacy level is most likely to be a woman aged between 55 and 65 . Her educational history includes basic education at best. She is likely to come from a family where the parents were also educated to a very low level. Her father is likely to have had a small business of his own. The person herself is likely to work as an unskilled blue-collar worker or manual worker in agriculture - or, considering her age, she is likely to have had an occupational career of this kind. Her salary is lower than the salaries of other people, even compared to her male colleagues doing the same kind of work with the same qualifications. This person rarely or hardly ever reads or uses information from written materials or fills in forms or does any arithmetic. The same is true of her private life. She often watches TV and rarely writes letters [Rabušicová 2002: 182-3].

It can be generalized that phenomena associated with literacy tend to be cumulative, in both a positive and a negative sense. This amounts to saying that in the Czech context, lower literacy levels are associated with lower education, less demanding jobs, lower salaries and poorer leisure time quality. These potential social handicaps tend to be socially reproduced, i.e. are passed on from one generation to another and are characterized by a considerable degree of "social heredity" [Rabušicová 2002: 18].

2 The preface to the IALS report [Literacy ... 1995] defines functional literacy as "reference to a specific behaviour, namely an ability to understand printed information and use it in everyday activities, private life, in one's job and to achieve one's individual goals and develop one's knowledge and potential". 
These conclusions raise questions which, although supplementary, are still fundamental: What is life actually like for people with inadequate levels of functional literacy? What is their life experience? Which problems do they face and how do they cope? What affects their lives including decision-making? Which life strategies do they choose and what is the impact of these strategies on other family members? How do they cope with the increasing literacy skills requirements?

More reliable answers to these questions are likely to arise from qualitative studies, as Disman puts it [1993: 286], "the goal of qualitative research is to understand a given phenomenon across as many of its dimensions as possible". And as Hendl [2005: 53] says, "the benefits of qualitative research include in-depth insights into cases including their history, relevant processes, context, and local contexts and circumstances".

Functional literacy, a relatively recently coined and researched phenomenon, is very instructive in showing how beneficial combining both methodologies can be - how mapping the distribution of functional literacy in the population via a macro-perspective can be complemented and enriched by a micro-view of the individual characterized by a certain level of functional literacy.

\section{Methodology}

The theme of the present study falls within the wide-ranging topic of adult functional literacy. The research problem involves life as experienced by a person suffering from low functional literacy, which can be summarized by the question: What is life like for a person suffering from low functional literacy? This question can be broken down into the specific questions listed above.

The biographical design of the research was selected from proven qualitative research methodologies as being "well-suited to capturing the complexity of a particular phenomenon that is opaque and unpredictable" [Švařiček 2007: 126]. It enables the history of the phenomenon to be recorded through the life story of an individual and his/her half-forgotten memories; the method is primarily not data collection but the reconstruction and interpretation of a person's life path by another person [Gavora 2000: 166; Hendl 2005: 130]. There is already a tradition abroad of using biographical design to research low levels of functional literacy [Döbert 2000; Egloff 1997; Nickel 2002]. The results of these studies are compared with those of the current analysis. 


\section{Method}

The selected method of data collection was a narrative interview divided into 3 stages: establishing an atmosphere of trust, the biographical narration itself and supplementary questioning. A series of topics were drawn up which were to be discussed in the third stage of the interview. However, since it turned out that a self-contained narrative cannot be elicited from the respondent, the selection of topics had to be used as the basis for the semi-structured in-depth interviews.

The interviews were conducted in a cumulative fashion. They were held within four weeks (October to November 2009) and their duration ranged from 54 to 68 minutes. The time between individual interviews was used to transcribe the audio recordings and to analyze the data, with the aim of adding questions of increasing specificity but also partly to uncover subjective meanings.

The interviews were held in the respondent's home. Considering the relatively close relations between the interrogator and her and her family, most of the in-depth interviews were preceded and followed by ordinary conversation. The overall time spent in the respondent's home was over 12 hours. This allowed the interrogator to get acquainted with the members of the respondent's household and partly to observe the respondent's role within the family and relations between the individual members of the family. Non-structured observation was thus a supplementary method of data collection.

\section{Case selection}

The case was selected in correspondence to the research problem and the main research question, thus limiting the potential respondents to persons whose functional literacy can be described as low or inadequate. The definition of low functional literacy was taken from the International Adult Functional Literacy Survey. The survey defined low functional literacy as levels 1 and 2 in the functional literacy test ${ }^{3}$, both of which were below the level corresponding to the minimum necessary for coping with complex challenges in everyday life and work [Rabušicová 2002].

3 Levels 1 and 2 in the prose literacy test correspond to the ability to locate information in texts, compare several pieces of information, or identify conflicting or paradoxical information. In the document literacy test, these two levels correspond to the ability to fill in personal data in a questionnaire or assign the required information to a specific part of a document based on a particular criterion. As far as numeric literacy is concerned, these two levels correspond to being able to use simple arithmetic such as adding or detracting numbers found in a text or a document. 
The findings of previous research into adult functional literacy indicated what the basic characteristics of persons suffering from low functional literacy might be and these were used to formulate a hypothetical model of such an individual (see above). These characteristics combined with the functional literacy test were the criteria for the selection of a typical case.

The following table outlines the basic characteristics of our respondent, consistent with the general hypothetical construct of the type of person characterized by a higher than average likelihood of having low functional literacy according to the quantitative results of IALS [Rabušicová 2002:182].

Table 1: Respondent's basic characteristics

\begin{tabular}{|c|c|}
\hline Name & Magda \\
\hline $\begin{array}{l}\text { Functional } \\
\text { literacy }\end{array}$ & $\begin{array}{l}\text { Functional literacy testing quickly revealed the respondent's } \\
\text { difficulties in terms of literacy skills. Immediately after I had } \\
\text { asked the respondent to fill in the basic SIALS file she responded } \\
\text { by saying her handwriting was not very legible and therefore it } \\
\text { would be better if the answers were recorded by me. I reassured } \\
\text { her that the test included only questions in which she had to } \\
\text { underline the appropriate option or to fill in a number. I also } \\
\text { mentioned that I was ready to help in case there was a problem. } \\
\text { Although the test included only } 6 \text { questions, it took the } \\
\text { respondent some time and it should be said that taking the test } \\
\text { was an unpleasant experience for her. Since one of the answers } \\
\text { in the basic file was incorrect, I decided her functional literacy } \\
\text { could be identified as inadequate/low without further testing. }\end{array}$ \\
\hline Age & 64 \\
\hline Education & $\begin{array}{l}\text { ISCED 3a: vocational training, no school-leaving certificate: One } \\
\text { year of vocational training as a spinner, vocational on the job } \\
\text { training as a lathehand }\end{array}$ \\
\hline Job position & $\begin{array}{l}\text { Blue-collar worker, skilled and unskilled work, no requirements } \\
\text { for literacy skills use (reading writing). }\end{array}$ \\
\hline $\begin{array}{l}\text { Socio-economic } \\
\text { status of } \\
\text { family of origin }\end{array}$ & $\begin{array}{l}\text { Family living in the country, parents' education at ISCED 2, } \\
\text { parents' jobs: unskilled farm worker (mother) and unskilled mine } \\
\text { worker (father), } 6 \text { children (one son-the eldest-and five } \\
\text { daughters), living together with maternal grandmother, } \\
\text { farmhouse in Kotovice village, field and orchard - collectivized } \\
\text { after WW2. }\end{array}$ \\
\hline $\begin{array}{l}\text { Marital status } \\
\text { and housing } \\
\text { conditions }\end{array}$ & $\begin{array}{l}\text { Divorced (twice); } 2 \text { adult children (a son and daughter); shared } \\
\text { household (rented apartment } 2+1 \text { ) with the divorced daughter } \\
\text { and a granddaughter. }\end{array}$ \\
\hline
\end{tabular}


Initial Entry into the field

The selection of the case and initial entry into the field were largely influenced by a desire to secure the respondent's trust and openness towards the researcher [Šed'ová 2007]. In addition, a respondent who was known to the researcher was selected in order to make sure the data were reliable and to minimize the risk of obtaining inaccurate information. There are however some drawbacks to their being an existing relationship between the respondent and the researcher (the subject's efforts to maintain the image she had consciously built over a period of time). The relation between co-author and respondent was however not too close; the co-author was generally aware of the respondent's situation and was familiar with several incidents from her life, communicated to her by their joint acquaintances. The role of the co-author towards the respondent can be labelled as one of an informed conversant.

To conform to research ethics, real names have not been used and local names and names of companies have been left out of the study. The respondent was made aware that the research would focus on characterizing her life ("What is life like for her?") and describe how she was coping with present-day challenges. She was also instructed about the expected time needed for the interviews. Based on this information, she formally consented to participate in the research.

\section{Data analysis}

The interview transcriptions were divided into meaningful wholes and open-coded. The resulting 138 codes were systemized by being assigned to categories. The categories were subsequently ordered so as to allow for a chronological development of the story.

\section{Results}

The results are presented in the form of an analytical story centring around three key topics suggesting a chronology: family life as a predisposition for using one's literacy skills, school years as an opportunity to acquire literacy skills, and work and life-style as factors weakening literacy skills.

\section{Family life: a predisposition for the use of literacy skills}

A person's life is pre-determined to a considerable extent, even before they are born: firstly, by the environment into which they will be born, and secondly, by the family s/he is to become a member of. Doležalová [2003] dis- 
cusses so-called local environment factors, which indicate that the risk of low functional literacy is higher in areas with limited job opportunities. The impact of the family factor (socioeconomic family status, parents' level of education, family values and needs) is even more crucial as an influence on functional literacy.

These two factors both have an impact in Magda's case. Magda comes from a rural area with limited job opportunities. Her mother looked after a family farm with livestock and a field that required tilling. Her father was a miner working at some distance from the family home who came back home only at weekends. The 'weekend marriage' lasted for over 10 years and produced 6 children: an older son and five daughters. The mother had to take care of the farm and the six children. People with low functional literacy often mention the absence/separation of a parent [Nickel 2002; Döbert, Hubertus 2000]. In the respondent's case, the separation was due to the lack of job opportunities in the home region and financial reasons.

The financial situation of the family was hard given the many children and the rather low incomes of the parents but became even harder as a consequence of agricultural collectivization, which severely reduced the family's property. Afterwards, the mother went to work in the agricultural cooperative and the father was employed locally as a delivery man.

Child labour is another factor often mentioned in connection with persons with low functional literacy [Nickel 2002]. Much of Magda's testimony on her her primary family and childhood consists of memories of the work duties she and her siblings had to perform.

"First we did it, the homework, and then we were yoked." (51)

Her use of the word 'yoked' is apt, considering the amount of work Magda had to do daily, but has the connotation of involuntariness too. Another part of her testimony indicates occasional boycotts of the duties on her part but it is also clear she rationalized the duties as time went on:

"Mother was also strict, most of all with what we were supposed to do and we didn't do, the duties I mean, well she had to be strict when Father was not at home. Well, what she planned for us had to be done, she could otherwise have gone mad with all that work. Grandmother, well, she was old, she could not help apart from cooking, so we had to." (30)

Attending school and doing homework were obstacles to the full engagement of the children in work around the house. During the vacations or rather non-vacations, the children worked the fields and around the house all day long. 
All activities, both during the school year and during the summer, were regulated by a strict daily and weekly routine including the division of labour.

"We had to go and pick wheat in the fields, either whole with the stalks for the cattle or just the grains in buckets or something. We went raspberry-picking in the woods for Mother to make jam from. [...] We had to go and pick endive and knotgrass for the rabbits. [...] We went nettle picking, and then we had to use that grinder thing, to cut them, that was another thing, and whosever day it was, they had to do the dishes. There was a rota, we had to take turns. [...] We had to clean the whole house on Wednesdays and Saturdays, wash the floors, and then do everything on Saturday including the yard, sweep the area in front of the house, the work was shared among us. Marie had the sitting-room to clean, me the kitchen and the two passage ways to go with it, the yard, and I swept the porch." (13-45)

The regularity, repetitiveness and precise order of the activities which constituted Magda's chores suggest an analogy with some of the attributes of ritual. Ritualization is a way of strengthening family organization patterns and family norms accentuating the fulfilment of duties, whether in connection to chores, school or religious practice. Those who participate in family rituals are reassured that they are members of the family and the rituals indicate the nature of family relations (parental authority, reliance on the others, dependence etc.).

Assigning work and checking up on it proves to be the only direct influence parents have on children. Punishments and rewards, as means of parental control, are also connected exclusively with chores.

"We were allowed to pick some strawberries in the wood and then we could have some cream with them, with egg whites and sugar, it was our reward in the summer." (17)

The reward was repeated (each summer) and the respondent perceived it as an appreciation of the work she and her siblings did in the fields.

Magda sees a difference in the use of negative motivation by her mother and by her father. While she views punishment by her mother as justified and forgives her (see the above quote from paragraph 30), she sees the father and his ways of punishing them in a negative light.

"He was too strict, in the first place, a despot, mad about every single small thing and he we also [pause], he sometimes shouted at Mother for nothing." (246) 
"It was rough for my brother until he was ten, or later too I guess. Father did not like him at all, he beat him senseless. His only son, that is." (55)

Use of inappropriate parental strategies (verbal abuse, shouting, physical violence) is also among the characteristics of family environments where individuals with low functional literacy typically grow up [Nickel 2002]. One or more family members are often ascribed the status of a "scapegoat" or a "black sheep". In Magda's family, the role was performed by her brother Martin, who found it most difficult to meet his parents' expectations concerning chores and school homework. Magda's explanation of the negative attitude of her father towards her brother is quite telling:

"Their relationship was no good at all. Well, we were the cheeky ones, the girls, when grandpa (father) came and we had to go and meet him, there was no bus then, well he came by train to (the name of the village) and we went quite a way to meet him. And so we threw ourselves at him, which was something our brother could not do, well they didn't have a good relationship." (58)

During the period when the father was coming home only for weekends, his anger was directed at his son. After he found the new job in the place where they lived his attacks became largely aimed at other members of the family (including the mother - see quote 246 above).

"It was bearable then, because he was home once a week, that's why; but when he worked where we lived, that was really horrible." (250)

The father is a bad character in Magda's narrative. His direct parental influence was minimal; Magda herself described it as being an anti-role-model.

"Well, it put me off... no-one would want to be like him, I do not have nice memories of him, my father." (311)

The degradation of the father in Magda's eyes is evident from the following quote too:

"He just couldn't cope without her (mother), always needed her to be around. He thought he was the head of the family but it was Mother." (35)

The mother is seen as the one who "made up for everything" (252) to the children. However, we should point out that Magda's narrative lacks specific situations to back up this claim about the mother/children relation. She is usually referred to as Mum (as opposed to the father who is referred to as ' $\mathrm{Fa}$ - 
ther' or Grandpa or by a personal pronoun). Magda views the sudden death of the mother as the severest crisis of her life next to her divorce. When asked how she thought her mother influenced her, she responded in the following way:

"My reliability is what I owe to her and my hard-working nature, I guess, at least partly." (243)

As stated above, what was emphasized in the family was performing one's duties. Time spent in other ways was narrowed down to compulsory attendance of Sunday mass and Sunday dinners. No other whole-family activities are mentioned in Magda's story. She did not recall her parents showing any interest in what she did in her free time. Magda associates leisure time in her childhood with playing outdoors with other children from the village. There is thus an absence of interests connected with higher culture and literacy culture. Magda's literacy skill development was strictly limited to formal education.

On the basis of the data collected, we can say that in the family education was not regarded as a value. Magda's narrative even suggests that her parents were not interested in helping to choose an educational path for their children after they completed primary school.

"Our parents neither pushed nor prevented us but we knew that not all of us could get [more] education." (110)

The parents showed an equally passive attitude to their children's homework. The children received no support from their parents or siblings.

"We studied on our own, no one helped us." (50)

The only signs of interest were in relation to checking the children's performance when they got their mid and end of school year reports.

"But they did read our school reports, even if we were not rewarded for that." (86)

Another piece of evidence that education was not regarded as important in the family is the fact that Magda was not able to recall which schools or careers her sisters and brother chose. It may be concluded that the life of the respondent in her primary family accurately corresponds to the typical childhood experience of individuals with limited literacy skills. These kinds of childhood are described by Nickel [2002: 4] as economically unstable, involving child labour, unstable relations, parental apathy and lack of interest in both emotional and educational terms, an absence of support when the chil- 
dren face problems, an insufficient provision of role models, minimal appreciation of education as a value etc.

\section{School years: literacy skills acquisition}

A number of studies [Verhoven 1994; Leij 1994] have concluded that not all children achieve sufficient levels of literacy to equip them to cope with everyday problems. Verhoven [1994] has described factors most likely to be associated with the insufficient acquisition of functional literacy in school. These factors are connected with school environment characteristics (many pupils per class, low education among teachers, poor access to sources of information etc.), with pupils' family backgrounds (family socioeconomic status, ethnicity, low expectations, low language culture) and pupil's subjective abilities (learning deficits, low IQ, volitional deficiency etc.). Leij [1994] believes there is usually a cluster of causes at the root of the problem, which makes it difficult to correct literacy deficits.

Inferior school performance (incomplete primary education, attending a vocational primary school rather than one with a standard curriculum etc.) is often associated with persons with low functional literacy who are also likely to have negative memories of school or to use escape strategies in connection with school (truancy etc.) [Leseman 1994]. This was however not true of Magda.

"Apart from our brother, we girls performed well. We had mostly B's." (44)

Her negative memories of school are only connected with the (rather supernatural) figure of the maths and physics teacher.

"Everyone was afraid of him, he was quite short, with a crew cut and those blue-green eyes of his, and angry, he would throw his keys at anyone who didn't know the answer, mostly the boys. That was him, we were scared of him, everyone would literally be praying before the lesson started because he was always yelling. He would rather yell at you than help you, he got mad at stupid kids, he didn't know how to encourage kids to get what they actually knew out of them. He would instantly get mad and so we would freeze up, you were too frightened to say anything, even if you did know it." (38)

This experience meant that Magda did not include maths and physics among the subjects she liked. It was similar with physical education, again due to an "idiot teacher" (42). What Magda liked was Czech. 
"Well, we had this really nice small teacher, her name was (surname),

I remember, she'd have a hard time with these rascals today, we would have never thought of doing what they do now." (214)

Whether she liked a subject or not depended not on the subject-matter nor on her ability to learn but the teacher's personality traits. This may mean that Magda did not relate to what she was learning in any personal way. Her only personal attitude (positive or negative) was to the teacher responsible for each particular subject. Magda's narrative provides evidence that her home study was limited to completing the compulsory homework (as a part of her daily routine - right after returning from school); she only did it more thoroughly on the odd occasion when she intended to ask the teacher to test her.

"We studied on our own, we only did our homework." (52)

"When I had studied it, I preferred to volunteer to be tested, to get it over and done with." (207)

She really viewed school as compulsory, as something that had to be done, as having no relation to her everyday life or even her future educational path. Her decision on where to carry on after primary school, limited as it was by the family's finances, did not reflect the subjects she had liked at school or other interests (she had no interests) but was based on circumstances.

"There was nothing I dreamed of in my childhood, and I had no idea what I wanted to do in life even later on. (167)

"There was this one opportunity at school, precisely because it was free, the vocational training, it was just for a year but we had to commit to working for them for two years on leaving school, in order to repay them, the company; so we would have to work for the company for two years after finishing the training. The school simply got information about vocational training positions and I knew I could not go and study, there was no money for that, so I chose the laundry." (209)

The respondent does not think back to the possible alternatives to her actual educational path, as they might have existed had there been no financial barrier.

"Q: If you could have decided without considering money, what would your decision have been about what to do after primary school? M: Well, I don't know, well, (long pause). I guess I would have studied (she says unconvincingly). O: What school? M: Well, I don't know what school." (239) 
Additionally, it may well be that the lack of finance is a rationalization of her lack of ambition and her passive attitude. Her sister, who had to make the same decision a year after Magda, decided to study at a regular secondary school (to become a train dispatcher) and to take the standard school-leaving exam, which must have been rather costly given that their home village was over $130 \mathrm{~km}$ from the school.

We may therefore hypothesize that the main barrier to the respondent developing her own educational potential was her lack of self-confidence ${ }^{4}$, which was reflected in her evident avoidance of failure (so-called negative motivation).

The respondent's summary of her school experience only partly matches the typical experience of people suffering from low literacy. Of the experience described by Nickel [2002], Magda exhibited mainly negative memories associated with specific teachers, a lack of awareness as to why one should learn, a lack of ambition and a passive attitude to choosing further education, and avoidance of potential failure. She also, quite surprisingly, had relatively good school results, regularly prepared for school, and had hardly any decidedly negative memories of school.

\section{Work and life style: weakening literacy skills}

People with limited education are largely limited to manual jobs. Manual work becomes both the consequence of their inadequate literacy, and its cause. This relates to Leseman's [1994] hypothesis of "varying practices": he believes people use texts in their adult lives to a varying extent. As was shown there was little requirement for different activities linked to reading and writing at work in all the jobs undertaken by the respondent.

"I only did manual work, I didn't have to read or write at all." (130)

Job opportunities are generally limited for people suffering from low literacy, which was very much the case with Magda, who, after completing the two compulsory years of work for the company she had trained with, accepted a job as an unskilled worker in mechanical engineering. Her job description was "doing what needed to be done" (224), which amounted to strictly manual work. She "lasted 17 years" (56) in that job, until she took maternity leave. She got another job as an unskilled labourer with a light mechanics and cleaning company afterwards. Here too, she "lasted 10 years" (102).

4 Insufficient self-confidence was shown to be a barrier to pursuing both education and a professional career in previous research by Egloff [1997]. 
The respondent often uses phrases such as "I got used to it" or "I lasted there" when speaking about her job history. This suggests she was not happy at any of the stages.

She says of the period when she was economically active:

"Well, I'm glad it's over." (228)

The absence of job satisfaction can be evidenced by another statement made by the respondent:

"I never seemed to look for something I would enjoy." (102)

A radical change in her job mobility occurred after the socioeconomic changes of 1989. She started to switch jobs often (kitchen assistant, working in a cleaning company, working in photocopying services, working for a frame-makers, shelf stacker etc.). It was her employers who terminated the jobs, for a variety of reasons (company closure, redundancies, frequent time off to look after an ill child).

"That was when I worked at the greengrocer's, it was terribly cold, I didn't like it at all, and they didn't renew my contract after 3 months." (105)

Then I worked in the kitchen, [...] a school cook, but Michal kept falling ill, so I had to leave within 3 months." (91)

The rapid replacement of one job by another ended when she started work as a housekeeper, first for a company and then, after retiring, on her own, for a particular family.

The strategy used by Magda in terms of her education, i.e. a lack of ambition and a passive attitude, seems to apply to her job history too. In both cases, the respondent has no idea of what would be her ideal job.

"I can't think of a single job I would like to do. (240)

To understand this strategy, it is necessary to define the contexts which may be linked to it in terms of both causes and consequences. The respondent's life strategy is connected with her fear of the consequences of her own decisions. Decisions are put off and made not of her own will but based on external factors or circumstances. This attitude is one of rejecting change and sticking to the familiar, which amounts to resignation about her personal development. The respondent's lack of self-confidence is evident again. She opts for solutions that eliminate the risk of failure. She acted in a self-dependent and active way only when switching jobs for the first time. 
"I approached the personnel department and they told me they had a vacancy, well, I didn't know anything about it." (225)

She relied on external help when looking for jobs after being on maternity leave.

"My job with (name of company) was arranged by a neighbour, that was that photocopying job, he worked for them too. And (name of company), that was an advert. Michal (her son) found that for me." (227)

"I joined (name of company) along with Marta (her daughter) when it was set up." (104)

People with low literacy have often been found to use all sorts of strategies to avoid situations requiring the use of literacy skills. They develop social networks instead, as Mikulecky [1982] says, that they can use to cope adequately with these situations. In addition to this, Magda avoided situations that required her to make her own decisions and where she could not rely on her previous experience. In these situations, she tends to rely on the authority of someone else, or she simply delegates the decision.

The first modus operandi, i.e. relying on someone else's authority, can be evidenced by the following anecdote:

"This was my friend's idea, she told me to apply for the cooperative thing, single accommodation was provided by the cooperative, and we paid a deposit of about two and a half thousand, and then we attended those meetings, and then we paid the instalments when they asked us how much money we had, and then I had that flat within just five years. [...] She was my roommate when we both trained, I was grateful to her, I would have never plucked up the courage. But she kept insisting. [...] Even my parents took out a loan then to help me out." (64)

Another important authority for Magda is her daughter Marta, with whom she shares the household. The wider family provides support too.

"We all go to choose the bigger things, like the fridge we bought a year ago, and then Marta and me go to have a look and see what we like, and we decide together. [...] Michal chose the mobiles for us but Marta chose the package, it's her I talk to most over the phone, so we have the same one. [...] Well, when I am at a loss, I try first to talk it over with Marta, or with Monika and Marek (relatives), and with Michal." (186) 
The evidence of the other strategy, i.e. not dealing with the situation and delegating the decision to someone else, can be found in her second divorce from the husband with whom she has two children ${ }^{5}$.

"My husband was hardly ever at home, first he did some moonlighting, it was mostly his friends who needed something or someone else he knew, he didn't get paid much for that or at least he didn't give much money to me, I have to put it this way now because I don't know what he did with the money, he went to the pub with friends, and then he came home less and less, and that did it." $(136)^{6}$

As for family life and bringing up her own children, Magda drew on the experience from her primary family, whether consciously or unconsciously. On the conscious level, she adopted the same daily routine, with the emphasis on fulfilling her duties, namely the chores and housework); on the unconscious level, she had low expectations about her children's education, she was happy with the minimum parental influence offered by their father, and she was not particularly interested in her children's problems and did not give them much support in coping with them.

"First they did their homework and only then could they go and play. That's the way to do it because no one can get a child to do her homework when she is tired. They should first get their homework done and then they should play." (257)

"My children had their duties, washing the dishes, emptying the bins, hoovering the carpets, and cleaning their shoes, they had duties." (295)

"I thought he would never study [...], I didn't even hope he would study at a secondary school. And then he said he would go and study but it would have to be at a school where there were no entrance exams." (219)

The last quote evidences Magda's son's taking over patterns of approach from his mother. He resorted to the strategy of taking advantage of 'favourable circumstances' out of fear of failure.

"They both wanted to, Michal did, I don't know about Marta but Michal wanted to find a school where there were no exams; his school

She has no children from her first marriage.

6 He moved out and sued for divorce. The first signs of his gambling addiction appeared from the beginning of the marriage; he has not seen the family since the divorce, they do not even know his whereabouts (he is in debt and homeless). 
record was quite good and there were no entrance exams to that school; he was terribly scared." (212)

Even her daughter's situation today resembles her mother's personal history. The daughter, although she has higher secondary education, works as an unskilled worker in a department store. The family situation clearly testifies to the social disadvantage thesis, for at least a third generation in this family.

The respondent's life style is shaped by her sharing the flat with her daughter and a granddaughter, which benefits all. Magda delegates the tasks she cannot cope with (paying bills, making decisions) to her daughter while the daughter uses her mother as a general household help and to take care of her daughter, in addition to getting some money from her and being able to share the flat with her.

"I take the little one to the kindergarten every day. Well, it's mostly me who cooks and does the shopping, there is no other option." (169)

"I mostly use the weekdays to do what I can't manage over the weekend when everybody is at home, which means I clean the flat, do the washing and ironing." (178)

"I never write, I just phone or send an SMS now and then. I don't even fill in any forms, only when it's really necessary, but that's hardly ever, it’s mostly Marta who does it." (202)

"Marta chose where we went on holiday, or we did it together. We have been twice, once in the Czech Republic and the other time in Bulgaria." (205)

Housekeeping is Magda's domain and it may be said that it is in carrying out these activities that we see signs of self-fulfilment.

"I wanted to work after retirement too, I would go mad just being at home, I can't imagine that. If we didn't have the little one, I don't know what I would do, just sit around all day [...] If you have no work to do at home, some ironing or something, you feel totally useless." (124)

Apart from cleaning the flat Magda's only other interests are taking care of her granddaughter (based on observation) and watching TV (they have a TV set in every room including the kitchen, i.e. three of them). ${ }^{7}$

7 The only leisure activity she said she shared with her husband was watching ice-hockey matches on TV. 
"Well, I watch TV all the time." (127) "I always have the TV on, not that

I would just sit in front of it but it's on in the background." (179)

Her favourite programmes include soap operas, romantic films and currently also the Superstar singing contest. Her preference for these genres seems to derive from her empathizing with one character or another (their situation and fate).

"I keep my fingers crossed for that Chodur (participant of the singing contest), if they kick him off, we'll have to stop saying that Czechs are musical. I was petrified when they recently challenged his right to win, I was sick at the thought. [...] But he was nervous too, poor thing, not knowing how it was going to turn out. But he sings so beautifully, if he doesn't win I don't know who will." (194)

The effort to make her life richer concerns members of her family too. Sharing the household with her daughter and granddaughter provides her with a sense of usefulness and value and is a source of a new experience she does not share actively but still feels herself to be a part of. This is reflected in her use of the first person plural even when she is talking of activities actually pursued by her daughter. One possible explanation of her use of the first person plural is her wish to present herself in a better light, which may mean she does not find her own life interesting enough and is thus mentioning her daughter's activities.

"M: We buy books. Marta borrows books from the library and I read along with her. She always brings something, we already have that author (Nora Roberts), so we choose, and then we read it.

O: You mean both of you?

M: Not me because I don't read so much, I don't have the time she has, I don't have time at work or at home." (286)

"M: We don't have a computer, Michal has one at his place. But we would at least like to have that 'labtob' thingy, we're going to get one.

O: And what are you going to use it for?

M: Well, I won't, I don't know how to use one, and I don't want to either." (182)

We have already quoted excerpts from the interview demonstrating that Magda's use for literacy skills in her free time is minimal (she hardly ever writes and she reads only sporadically). She hardly ever enters into commu- 
nication with institutions (such as financial ones) and she refuses to use any of the bank products on offer (savings accounts and insurance). "It's better not to pay anything." (282) She does not vote in elections either, explaining it away by her mistrust of politicians.

"I don't vote because I don't know who I should vote for, because they are all..., I don't know who I should choose, they have all turned out to be tricksters." (200)

Her use of phrases such as who I should vote for, who I should choose shows she does not know which behaviour is the appropriate one and therefore chooses to evade decisions, another proof of her life strategy.

Both her job history and her life style show many of the characteristics typical of the adult lives of people with low literacy skills as described in other research. Dobert and Hubertus [2000: 52] call that "a nexus of causes of a lack of literacy found in the family, at school and in adulthood". The components are those such as a lack of trust in one's own abilities, fear of failure, difficulties experienced in pursuing everyday activities, resulting in a search for replacement strategies such as delegating solutions, identification with others, relying on other people's authority etc. Cross-generational transfer of these strategies as a mechanism of social deficit reproduction also plays a role.

\section{Summary and conclusions}

The starting point for this study was a hypothetical model of an individual with inadequate literacy skills. We attempted to answer the research question "What is life like for a person with inadequate literacy skills" using qualitative research. A biographical design was used and all the information was arranged according to life stages, thus providing a starting point for creating a picture of "life for someone with inadequate literacy".

Unlike the authors quoted above, we did not have the benefit of easy access to people with poor literacy skills as there are very few adult education courses in the Czech Republic to feed the research as is the case abroad. It can however be assumed that those who attend basic adult education courses can be distinguished by their awareness of their shortcoming, which - as the IALS research has shown - is not typical of people with inadequate literacy skills.

Drawing on characteristics from the theoretical model and a literacy skills test, a subject, Magda, was selected, who revealed her life experience and her view of it in interviews, thus giving us some insight into the life of a person 
with low/insufficient literacy skills. The experience she shared has largely confirmed conclusions of previous research while yielding additional results.

The insufficient literacy skills observed in the respondent resulted from the low socioeconomic status of the family (low education of parents, parents working as unskilled workers, financial insecurity) as well as other important family background characteristics such as a high number of members in a household without their own income, the absence of a parent, lack of interest in high culture, undervaluation of education in the family, low expectations regarding children's educational path, a lack of support in preparation for school, an indifference to complex individual development, inappropriate parental strategies, minimal parenting by the father, child labour at home and work. All of the above were found to shape a person's predisposition to use literacy skills.

The top priority in the family was performing one's duties, whether in connection with domestic chores, school or religious tasks. Performing one's duties seems to have been a cohesive family strategy as all members of the family seemed to subscribe to it in one form or another, which could not be said of other activities. In addition, performing one's duties was firmly structured: the regularity, repetitiveness and prescribed order of activities are characteristics qualifying the phenomenon as a domestic ritual used by the individual members of the family to reassure themselves of their membership (their share of rights and duties) and the nature of their relations.

The research on initial education has yielded mixed information. The respondent had no real problems with school performance nor any decidedly negative memories of school. There were, however, other issues which prevented the respondent from fully exploiting the potential of her school years as an opportunity for further development.

Firstly, her case confirms one of the conclusions of the research by Egloff [1997], namely that people with inadequate literacy skills do not regard the knowledge and skills gained through compulsory schooling as important for their everyday lives. This is particularly striking in the case of the respondent whose school performance can be called 'good'. One of the roles of school should be, especially with regard to pupils from socially disadvantaged families, to motivate pupils to use literacy skills to meet their individual needs.

The second generally recognized conclusion is that individuals with inadequate literacy skills have negative self-images (they lack self-confidence) [Nickel, Döbert 2000; Egloff 1997]. They opt for failure avoidance strategies. With our respondent, this strategy was reflected in the choices she made in terms of her education and later her job history.

Our respondent's life as an employee was characterized by a series of unskilled worker jobs dominated by manual work. She has never used her 
literacy skills in any of her jobs. The changing post-1989 labour markets made her switch jobs often. Despite being unhappy about her jobs, she only looked for another one when she had lost the one she had previously held. Alongside her fear of unemployment, another explanation might be the strategy mentioned above: eliminating the risk of failure in potential unfamiliar situations and roles.

A person with inadequate literacy skills often faces having to make decisions about things they are unfamiliar with, and thus they avoiding them. They do not possess the skills to allow them to understand these phenomena and situations. Their preferred strategy is to delegate the responsibility for making these decisions to other people, directly or indirectly. They also delegate activities associated with use of literacy skills [Mikulecky 1982; Nickel, Döbert 2000], which was the case of the respondent in this study as well.

Using literacy skills in her jobs or private life is not something the respondent is familiar with, and her interests may also be regarded as limited (watching TV, taking care of the household and her granddaughter). Her failure to use them has led to their deterioration.

The most marked characteristic of the whole life story seems to be the absence of the respondent's own goals and expectations, evidently in connection with her lack of self-confidence. That her life has changed is due to external circumstances rather than her own will. The insufficient literacy skills prevented her from understanding many problems, and led her to stop facing them actively and to rely on the help of others. This "passive attitude to life" seems to be an important undercurrent in the respondent's life, and was also evident in her primary family and continues to be so in the stories of her own children. The reproduction potential of social disadvantage is clearly evident.

It might be assumed that the escalating requirements put on people in the present era will often frustrate individuals with inadequate literacy skills as they are likely to face difficult situations that repeatedly challenge their skills. These people mostly carry out their lives based on their experience in their primary family, making them "fall one generation behind" compared with their peers. In addition to the consequences of functional literacy currently recognized, new ones are likely to appear.

\section{References}

Disman, M. 1998. Jak se vyrábí sociologická znalost: Příručka pro uživatele. Praha: Karolinum.

Döbert, M. Huberts, P. 2000. Ihr Kreuz ist die Schrift Analphabetismus und Alphabetisierung in Deutschland. Münster: Bundesverband Alphabetisierung e.V. 
Doležalová, J. 2005. Funkčni gramotnost - proměny a faktory gramotnosti ve vztazích a souvislostech. Hradec Králové: Univerzita Hradec Králové, Pedagogická fakulta, Gaudeamus.

Egloff, B. 1997. Biographische Muster "funktionaler Analphabeten“: Eine biographieanalytische Studie zu Entstehungsbedingungen und Bewältigungsstrategien von ,funktionalem Analphabetismus“ [online], srpen 2009 <http://www.die-bonn.de/esprid/ dokumente/doc-1997/egloff97_01.pdf>

Gavora, P. 2000. Úvod do pedagogického výzkumu. Brno: Paido.

Hendl, J. 2005. Kvalitativní výzkum: Základní metody a aplikace. Praha: Portál.

Hubertus, P. 1991. Alphabetisierung und Analphabetismus. Eine Bibliographie. Bremen: Schreibwerkstatt für neue Leser und Schreiber.

Leij van der, A. 1994. Towards taxonomy of early literacy difficulties. In Verhoeven, L. (ed.) Functional Literacy. Theoretical Issues and Educational Implications. Amsterdam/Philadelphia: John Benjamins Publishing Company, 349 - 370.

Leseman, P. 1994. Socio-cultural determinants of literacy development. In Verhoeven, L. (ed.) Functional Literacy. Theoretical Issues and Educational Implications. Amsterdam/Philadelphia: John Benjamins Publishing Company, 161 - 184.

Literacy, Ekonomy and Society. Results of the first International Adult Literacy Survey. 1995. Paris, Canada: OECD and Statistics Canada.

Mikulecky, L. 1982. Job literacy: the relationship between school preparation and work place actuality. Reading Research Quarterly, 17: 400 - 420.

Nickel, S. 2002. Funktionaler Analphabetismus -Ursachen und Lösungsansätze hier und anderswo [online]. Písemné podklady k přednášce konané dne 30. 05. 2002 v rámci. IV. Internationalen Woche im Fachbereich Erziehungs- und Bildungswissenschaften der Universität Bremen. Bremen: Universität Bremen, srpen 2009 <http:// elib.suub.uni-bremen.de/publications/ELibD890_Nickel-Analphabetismus.p>

Oplatková, P. 2010. Funkční gramotnost v životě člověka. Diplomová práce. Brno: Filozofická fakulta, Masarykova univerzita.

Rabušicová, M. 2002. Gramotnost: staré téma v novém pohledu. Brno: Masarykova univerzita, Georgetown.

Šed’ová, K. 2007. Proces kvalitativního výzkumu a jeho plánování. In Švařiček, R., Šed’ová, K. (eds.) Kvalitativní výzkum v pedagogických vědách: pravidla hry. Praha: Portál, $51-82$.

Švařiček, R. 2007. Kritéria kvality kvalitativního výzkumu. In Švařiček, R., Šed'ová, K. (eds.) Kvalitativní výzkum v pedagogických vědách: pravidla hry. Praha: Portál, $28-50$.

Švaříček, R. 2007. Biografický design. In Švařiček, R., Šed’ová, K. (ed.) Kvalitativní výzkum v pedagogických védách: pravidla hry. Praha: Portál, 126 - 141.

Verhoeven, L. 1994. Modeling and promoting functional literacy. In Verhoeven, L. (ed.) Functional Literacy. Theoretical Issues and Educational Implications. Amsterdam/Philadelphia: John Benjamins Publishing Company, 3 - 34. 


\section{Authors}

Milada Rabušicová, Ph.D., Professor

Pavla Oplatková, Mgr.

Masaryk University

Faculty of Arts

Department of Educational Sciences

Arne Nováka 1

60200 Brno

Czech Republic

E-mail: milada@phil.muni.cz 